\author{
Praca poglądowa/Review paper
}

\title{
Obraz hemoreologiczny w chorobach nowotworowych
}

\author{
Hemorheological picture in cancerous diseases
}

\author{
Anna Marcinkowska-Gapińska ${ }^{1}$ \\ ${ }^{1}$ Zakład Biofizyki, Katedra Biofizyki Uniwersytet Medyczny im. K. Marcinkowskiego w Poznaniu, Polska
}

\section{Streszczenie}

Hemoreologia jest nauką zajmującą się badaniem przepływu krwi w naczyniach krwionośnych. Parametry reologiczne mają znaczenie w patogenezie wielu chorób, w tym także w chorobach nowotworowych. Determinantami przepływu krwi są wartość hematokrytu, lepkość osocza, lepkość krwi pełnej oraz zdolność erytrocytów do deformacji i agregacji. Zmiany wartości lepkości krwi pełnej, lepkości osocza jak podwyższoną skłonność erytrocytów do agregacji i obniżoną zdolność do deformacji obserwuje się w przypadku wielu zmian nowotworowych. Wielu autorów wskazuje na możliwość wykorzystania badań reologicznych w prognozowaniu stopnia zawansowania choroby jak również wyboru metody terapeutycznej. Postulowane jest również modyfikowanie nadmiernej lepkości jako jednej z koncepcji leczenia chorób nowotworowych.

\begin{abstract}
Hemoreology is a branch of science dealing with the study of blood flow in blood vessels. Rheological parameters are important indicators of the pathogenesis in many diseases, including cancer. Blood flow determinants are hematocrit, plasma viscosity, whole blood viscosity, and the ability of erythrocytes to deform and aggregate. Changes in the value of whole blood viscosity, plasma viscosity and other parameters such as increased erythrocyte aggregation tendency and reduced deformability are observed in many neoplastic lesions. Many authors point to the possibility of using rheological tests to predict the degree of disease progression as well as to make a choice of the therapeutic method. It is also postulated that reduction of excessive viscosity could be a good concept for the treatment of cancer.
\end{abstract}

Stowa kluczowe: hemoreologia, lepkość krwi, lepkość osocza, choroby nowotworowe

Keywords: hemoreology, blood viscosity, plasma viscosity, cancer

Adres do korespondencji

Anna Marcinkowska-Gapińska

Zakład Biofizyki,

Katedra Biofizyki Uniwersytet Medyczny im. K. Marcinkowskiego w Poznaniu ul. Grunwaldzka 6, 60-78o Poznań, Polska

Telefon. +48618546691

e-mail: margap@ump.edu.p 


\section{Wprowadzenie}

Nauką zajmującą się badaniem przepływu i deformacji płynów jest reologia [1-3]. Analizą funkcjonowania układu krążenia, w którym występują zjawiska opisywane przez mechanikę płynów, specyficznymi uwarunkowaniami przepływu krwi w naczyniach krwionośnych wynikającymi z właściwości obwodowego układu krążenia jak i fizykochemicznych właściwości krwi, zajmuje się hemodynamika i hemoreologia [4-7]. Biologiczną funkcją krwi jest zaopatrywanie tkanek i narządów w tlen oraz w substancje odżywcze przy równoczesnym usuwaniem z nich produktów odpadowych przemiany materii. Ważną rolą jest również regulowanie temperatury ciała. Krew krąży w naczyniach krwionośnych o własnościach lepkosprężystych, stanowiących zamknięty obwód naczyń, o średnicy od $3 \mathrm{~cm}$ do około $5 \mu \mathrm{m}[4,6,7]$. Krążenie krwi w organizmie żywym warunkuje różnica ciśnień między układem tętniczym a żylnym, utrzymywana przez rytmiczne skurcze serca, powodujące pulsacyjny ruch krwi z cyklicznie zmienną prędkością jej przepływu. Zgodnie z prawem Hagena-Poisseuille’a objętość cieczy przepływającej przez cylindryczne naczynie w jednostce czasu jest wprost proporcjonalna do czwartej potęgi promienia naczynia i do różnicy ciśnień wywołujących przepływ, natomiast odwrotnie proporcjonalna do lepkości cieczy i długości naczynia $[5,7,8]$. Na przepływ krwi w układzie krwionośnym wpływają także fizykochemiczne właściwości samej krwi i zjawiska w niej zachodzące podczas przepływu, takie jak tworzenie i rozpad agregatów erytrocytów, czy zmiana kształtu erytrocytów. W zakresie niskich prędkości ścinania procesem dominującym jest agregacja erytrocytów, a w zakresie wysokich prędkości ścinania ich deformacja [4,6-9]. Reologiczna charakterystyka krwi pozwala zakwalifikować ją do cieczy pseudoplastycznych o właściwościach tikosotropowych i lepkosprężystych, a jej złożone właściwości reologiczne wynikają zarówno z właściwości erytrocytów jak i osocza $[4,9]$. Za główne czynniki wpływające na przepływ krwi uważa się hematokryt, lepkość krwi pełnej, lepkość osocza, zdolność erytrocytów do agregacji, deformacji i orientacji [4-7,9,10]. Badania hemoreologiczne obejmują ocenę lepkości krwi pełnej w szerokim zakresie prędkości ścinania, lepkości osocza oraz ocenę skłonności erytrocytów do agregacji i deformacji [4,6,9]. Zmiany wartości parametrów hemoreologicznych obserwuje się w przypadku wielu chorób między innymi w niewydolności naczyń wieńcowych serca, zawału mięśnia sercowego, zatorów, zaburzeń krążenia mózgowego i siatkówkowego, chorobie niedokrwiennej kończyn, cukrzycy, anemii, a także chorób nowotworowych [4,6,7,10-14].

Celem niniejszej pracy był przegląd doniesień literaturowych związanych $\mathrm{z}$ analizą zmian wartości parametrów reologicznych krwi w przypadku chorób nowotworowych.

\section{Profil hemoreologiczny pacjentów z chorobami nowotworowymi.}

Czynnikiem odgrywającym ważną rolę zarówno we wzroście guza jak i wykrywaniu oraz leczeniu nowotworów jest mikrokrążenie. Naczynia krwionośne powstałe w procesie angiogenezy dostarczają niezbędnych składników odżywczych umożliwiając wzrost guza oraz usuwają produkty przemiany materii. Obecność rozwijającego się guza lub innej zmiany o charakterze nowotworowym może zmieniać parametry reologiczne krwi [12-15]. Analiza profilu hemoreologiczne pacjentów z chorobami nowotworowymi wskazuje na podwyższone wartości takich parametrów jak skłonność erytrocytów do agregacji, sztywność erytrocytów, lepkość osocza oraz poziom fibrynogenu i globulin w stosunku do grupy osób zdrowych [12-15]. U pacjentów w zaawansowanym stadium choroby obserwuje się również wzrost lepkości krwi pełnej przy prawidłowym lub obniżonym poziomie hematokrytu [12-15]. Zmiany te nie tylko zaburzają przepływ krwi w mikrokrążeniu, ale również wpływają na mikrokrążenie guza, a przez to na początek przerzutów jak i na skuteczność leczenia [12].

Wartości lepkości krwi pełnej jak i pozostałych parametrów hemoreologicznych zależą od rodzaju choroby, długości jej trwania, chorób towarzyszących i przyjmowanych leków [4,6,10,11]. W doniesieniach literaturowych zwraca się uwagę na obecność występowania w organizmach żywych mechanizmów regulacji własności hemoreologicznych poprzez zmianę skłonności erytrocytów do agregacji i deformacji, kompensację podwyższonej lepkości krwi przez obniżenie wartości hematokrytu, a także poprzez zmianę składu białkowego osocza, co w konsekwencji powoduje zmianę jego lepkości [15-22]. Stosowanie terapii wpływających na właściwości reologiczne krwi może również wpływać na przebieg choroby podstawowej 
$[15,21,23,24]$. Te obserwacje potwierdzają się również w przypadku chorób nowotworowych $[12,15,22,24-$ 28].

Zdolność krwi do przenoszenia tlenu zależna jest od wartości hematokrytu (Hct) [4,9,29]. Występujące u pacjentów z chorobą nowotworową połączenie podwyższonej lepkości osocza i skłonności erytrocytów do agregacji, wysokiej aktywności agregacyjnej płytek krwi oraz zmniejszonej liczby erytrocytów (obniżony poziom Hct) powoduje upośledzenie skuteczności transportu tlenu we krwi, a w konsekwencji niedotlenienie w mikrokrążeniu sprzyjające zakrzepicy, rozrostowi guza i przerzutom [12,30,31]. Z kolei wzrost guza może prowadzić do niedotlenienia tkanek, a w konsekwencji niedotlenienie tkanek staje się silnym bodźcem do ekspresji genów kodujących czynniki sprzyjające wzrostowi guza. Niedotlenienie jest istotnym warunkiem w cyklu autogennego rozprzestrzeniania się nowotworu. Markerem obecności niedotlenienia tkanek może być obecność wysokiej lepkości krwi, która występuje w wielu chorobach nowotworowych [12,31,32]. Dotlenianie tkanki nowotworowej zostało niedawno ocenione jako ważny warunek skuteczności radioterapii w raku szyjki macicy [28].

Kolejnym czynnikiem hemoreologicznym jest skłonność erytrocytów do agregacji. W przypadku pacjentów z chorobą nowotworową obserwuje się podwyższoną wartość tego parametru a także wzrost stężenia fibrynogenu i globulin, obniżony stosunek albumin do fibrynogenu, w konsekwencji prowadzi to do podwyższonej wartości lepkości osocza [12,14]. W przypadku raka płuc i jelit, raka piersi, jajnika, macicy, prostaty, czerniaka obserwuje się istotny wzrost agregacji krwinek czerwonych $[12,14,15]$. U pacjentów z czerniakiem zaobserwowano ponadto spadek wartości hematokrytu i spadek elastyczności erytrocytów [12]. U chorych z rakiem głowy i szyi zaobserwowano statystycznie istotny wzrost lepkości osocza, wzrost skłonności erytrocytów do agregacji, wzrost poziomu fibrynogenu oraz podwyższoną sztywność krwinek czerwonych [13]. Ponadto w tej grupie chorych zaobserwowano podwyższoną wartość lepkości krwi przy prawidłowym lub obniżonym poziomie hematokrytu [13]. W przypadku pacjentek ze zmianą nowotworową o podłożu ginekologicznym zaobserwowano wzrost wartości czynników wpływających na lepkość krwi w momencie widocznych klinicznie przerzutów [15]. U chorych z rakiem piersi i rakiem jajnika zaobserwowano istotnie wyższą lepkość osocza w grupie osób, które nie przeżyły w porównaniu z chorymi którzy przeżyli [32]. W nowo zdiagnozowanym raku obserwuje się wzrost lepkości osocza i podwyższoną skłonność do agregacji, a w konsekwencji nadlepkość kompensowaną przez niedokrwistość [15]. Tempelhoff i wsp. donosi, że u pacjentów z rakiem jajnika rozwój zakrzepicy żył głębokich pooperacyjnie i podczas chemioterapii wiązał się z niezależnym od hematokrytu zwiększeniem lepkości krwi charakteryzującym się wysoką lepkością osocza przy prawidłowej lub niskiej wartości hematokrytu [33]. Uważa się, że jedną z koncepcji leczenia raka może być modyfikacja nadmiernej lepkości, szczególnie osocza, co może poprawić odpowiedź organizmu na radioi chemioterapię oraz zapobiegać zakrzepicy, częstego powikłania w chorobach nowotworowych wpływając tym samym na poprawę wskaźnika przeżywalności pacjentów [15,24,31,32,34]. Analiza zmian wartości parametrów hemoreologicznych, takich jak skłonność erytrocytów do agregacji i lepkość osocza może mieć istotne znaczenie, także ze względu na to, że zdarzenia zakrzepowo-zatorowe są przyczyną powikłań w procesie chirurgicznego i chemioterapeutycznego leczenia nowotworów [24].

Zakres zmian reologicznych koreluje z postępem choroby i jej rokowaniem w niektórych typach raka. Zaawansowanie choroby było w wyższym stadium u pacjentów z wysoką wartością lepkości krwi pełnej $[12,13,15,24,32]$. Naczynia krwionośne i limfatyczne stanowią nośnik dla komórek rakowych dla przerzutów do odległych narządów [12]. Lokalny przepływ krwi odgrywa ważną rolę w przekazywaniu podawanych podczas chemioterapii i immunoterapii środków farmakologicznych. Również w radioterapii skuteczność leczenia zależy od lokalnego stężenia tlenu, które zależy od lokalnego przepływu krwi [12,28]. Wzrost guza prowadzący do niedotlenienia tkanek powoduje, że niedotlenienie staje się bodźcem do ekspresji genów sprzyjających rozrostowi guza [32]. Niedotlenienie z kolei wpływa na rozprzestrzenianie się nowotworu. Adaptacja do niedotlenienia przez proliferujące komórki nowotworowe powodujeindukcjęgenów regulujących metabolizm beztlenowy [31].

Niedokrwistość często występuje u chorych ze zmianami nowotworowymi, a anemia powoduje negatywny wpływ na ich przeżycie i zwiększa zmęczenie chorych [35]. W przypadku chorych z rakiem niedokrwistość 
często wzrasta wraz z chemioterapią, powodując konieczność stosowania transfuzji [29]. Zastosowanie transfuzji krwi u pacjentów z nieoperowalnym rakiem przełyku poddawanych chemioterapii skojarzonej znacznie poprawiło wskaźnik ich przeżycia [36]. Tempelhoff i wsp. [15] wskazuje na czynnik reologicznych przyczyniającysiędoanemii upacjentówzchorobaminowotworowymi. Wysokalepkośćkrwiwynikająca często zwysokiejlepkości osocza powoduje hamowaniei modulacjęprodukcji erytropetyny [15], podobniejak zapalna promocja produkcji cytokin [35]. Terapia rekombinowaną erytropoetyną u pacjentów z niedokrwistością nowotworową przyczyniła się do zwiększenia poziomu hemoglobiny i poprawy profilu hemoreologicznego poprawiając efektywność chemioterapii [37]. Działanie hemoreologiczne było korzystniejsze w przypadku zastosowania terapii z wykorzystaniem epoetyny niż w przypadku hemotransfuzji. Wskaźnik wydajności transportu tlenu po transfuzji zmieniał się nieznacznie, podczas gdy po terapii zwiększył się o 14\% pomimo wysokiej lepkości krwi [37]. Stosowanie środków stymulujących erytropoezę zmniejszają potrzeby transfuzji krwi podczas chemioterapii, jednak zaobserwowano zwiększone ryzyko wystąpienia zdarzeń zakrzepowozatorowych bez zwiększanie ryzyka śmiertelności. Wyjaśnieniem tego zjawiska może być utrzymująca się podwyższona lepkość krwi [35].

Modyfikacja przepływu krwi przez guzy z wykorzystaniem środków chemicznych ma na celu poprawę efektywności leczenia nowotworów z wykorzystaniem radio- i chemioterapii [25,26,38]. Poszerzenie wiedzy na temat molekularnych mechanizmów i znajomość mikroprzepływów ma istotne znaczenie w projektowaniu zarówno nowych metod jak i leków przeciwnowotworowych, a także w postępowaniu operacyjnym [27,31,38]. Ostatnie badania wykazały, że w komórkach nowotworowych piersi, prostaty, żołądka, jelita grubego, płuca, pęcherza i endometrium w warunkach niedotlenienia i nekrotyczności obserwuje się zwiększoną aktywność genów stymulujących ekspresję cytokin, zwłaszcza VEGF odpowiedzialnego za wzrost śódbłonka naczyniowego prowadząc w konsekwencji do zmniejszenia światła naczyń i tworzenia skrzepów [31]. Eliminacja niedotlenionych komórek może wzmocnić odpowiedź komórek na radio- i chemioterapię, a także zmniejszyć działania niepożądane (zakrzepica) [31].

Podwyższoną wartość lepkości krwi, określaną często jako zespół nadlepkości obserwuje się w przypadku chorób takich jak czerwienica, makroglobulinemia Waldenströma, szpiczak mnogi [11,34,3942]. Zaburzenia reologiczne w czerwienicy mogą być przyczyną poważnych powikłań neurologicznych, czy zakrzepicy kończyn dolnych [43]. Shin D.W. i wsp. zauważyli, że pomiary lepkości krwi są niedostatecznie wykorzystywane, pomimo, że zespół nadmiernej lepkości w dyskrazji komórek plazmatycznych (PCD) i zakrzepica w raku mieloproliferacyjnym (MPN) są głównymi przyczynami zachorowalności i umieralności [42]. Na wykorzystanie lepkości krwi jako markera kontrolnego w pacjentów ze zdiagnozowanym chłoniakiem nieziarniczym (NHL) zwraca uwagę także Utkan G. i wsp. [44], a Uggla B. i Nilsson T.K. uważają, że chociaż lepkość osocza w dyskrazjach (PCD) jest znacznie podwyższona, to lepkość krwi pełnej jest lepszym markerem [39]. Caimi G., i wsp. zauważają, że w profilu hemoreologicznym u pacjentów ze szpiczakiem mnogim (MM) uwagę zwraca podwyższona lepkość osocza, spadek wartości hematokrytu oraz spadek odkształcalności erytrocytów, co może mieć istotny wpływ na mikrokrążenie [45]. Współwystępowanie szpiczaka mnogiego i anemii sierpowatej wykazało, że lepkość krwi tego pacjenta była podwyższona w porównaniu do krwi pacjenta z anemią [46]. Klemencic S. i Perkins J. w pracy Diagnosis and management of oncologic emergencies [47] zwracają uwagę na coraz częściej pojawiające się nagłe przypadki onkologiczne. Autorzy Ci podkreślają, że pacjenci ze z makroglobulinemią Waldenströma, szpiczakiem mnogim, białaczką oraz czerwienicą narażeni są na zespół nadlepkości, powodujący względną hipoperfuzję, która może naśladować inną patologię choroby. Pacjenci z nadlepkością mogą mieć objawy mylone z udarem mózgu, duszności mylone z zatorem płucnym lub niewydolnością serca lub zmieniony stan psychiczny mylony z posocznicą [47].

Ważnym czynnikiem reologicznym jest agregacja erytrocytów. Wzrost agregacji obserwuje się w przebiegu wielu chorób w tym, u chorych onkologicznych [4,11,12,22,30]. Jednym z poważnych powikłań u pacjentów operowanych z powodu raka piersi jest obrzęk limfatyczny. Zaobserwowano, że w tej grupie pacjentów agregacja czerwonych krwinek jest podwyższona [48]. Na podstawie przeprowadzonych badań lepkości osocza, agregacji erytrocytów i morfologii naczyń włosowatych oraz przepływów w grupie pacjentów z z rakiem piersi z obrzękiem i bez zapostulowano istnienie nieznanego białkowego czynnika sprzyjającego 
agregacji erytrocytów i obrzękowi limfatycznemu [48]. Również u chorych z różnymi rakami trzewnymi obserwowano nieprawidłowości w agregacji krwinek czerwonych [14]. Lepkość osocza i tendencja do agregacji czerwonych krwinek były istotnie wyższe u chorych niż w grupie kontrolnej przy znacznie podwyższonym stężeniu poziomu fibrynogenu i globuliny wpływając w efekcie na częstość występowania żylnej choroby zakrzepowo-zatorowej [14].

Przepływ krwi w naczyniach krwionośnych zależy nie tylko od właściwości fizykochemicznych krwi, ale także od stanu naczyń krwionośnych [4,6,7]. W nowotworach hematologicznych stwierdzono, że chemioterapia, radioterapia oraz przeszczep krwiotwórczych komórek macierzystych przyczyniają się do wzrostu sztywności tętnic [49]. Mechanizmami wpływającymi na podwyższoną sztywność tętnic są stres oksydacyjny, upośledzona homeostaza ściany naczyń, dysfunkcje śródbłonka i apoptoza śródbłonka, nadekspresja cytokin zapalnych, miażdżyca naczyń oraz zwiększona lepkość krwi [53]. Lepkość krwi odgrywa ważną rolę w utrzymaniu hemostazy naczyniowych. Wydaje się, że monitorowanie i modyfikacja lepkości krwi może mieć istotne znaczenie w zapobieganiu oraz leczeniu chorób [50]. U pacjentów onkologicznych stwierdzono, że obecność złośliwej zmiany wpływa na układ hemostatyczny, a układ hemostatyczny wpływa na nowotwór złośliwy. Głównym odziaływaniem są liczne nieprawidłowości krzepnięcia przyczyniające się do zwiększenia zakrzepicy i krwotoków zależne od typu i stadium choroby [15,50].

\section{Podsumowanie}

Podwyższone wartości parametrów hemoreologicznych u chorych ze zmianami nowotworowymi wynikają ze zmian w składzie osocza w wyniku podwyższonych stężeń frakcji fibrynogenu i globulin. Kolejnym czynnikiem wpływającym zna niekorzystną zmianę warunków przepływu krwi jest podwyższona skłonność erytrocytów do agregacji, obniżenie zdolność erytrocytów do deformacji jak również wzrost sztywności tętnic. Wszystkie te czynniki wpływają pośrednio lub bezpośrednio na wzrost lepkości krwi pełnej u chorych z chorobami nowotworowymi w stosunku do grupy kontrolnej. Na uwagę zasługuje podkreślenie, że zaobserwowano korelację - im cięższy jest stan pacjenta tym parametry lepkościowe są bardziej podwyższone. Jest to jeden z powodów dla którego postuluje się większe wykorzystanie pomiarów lepkości krwi w tej grupie chorych.

\section{Bibliografia}

[1] Kiliański T, Dziubiński M, Sęk J, Antosik K, Wykorzystanie pomiarów właściwości reologicznych płynów w praktyce inżynierskiej. Warszawa: EKMA Krzysztof Antosik; 2009.

[2] Schramm G, Reologia - podstawy i zastosowania, Poznań: Ośrodek Wydawnictw Naukowych. 1998.

[3] Kembowski Z, Reometria płynów nienewtonowskich, Warszawa: Wydawnictwo Naukowo-Techniczne; 1973.

[4] Baskurt OK, Hardeman MR, Rampling MW, Meiselman HJ, Handbook of Hemorheology and Hemodynamics, Amsterdam, Berlin, Oxford, Tokyo, Washington: IOS Press DC; 2007.

[5] Milnor WR, Hemodynamics, Baltimore, Maryland, USA: Williams \& Williams, 1989.

[6] Wasilewski J, Kiliański T, Biomechaniczna przyczyny miażdżycy, Łódź: Monografie Politechniki Łódzkiej; 2011.

[7] Bębenek B, Przepływy w układzie krwionośnym, Kraków: Wydawnictwo Politechniki Krakowskiej; 1999.

[8] Fåhraeus R, Lindquist T. The viscosity of the blood in narrow capillary tubes. Am J Physiol 1931;96:562568.

[9] Lerche D, Bäumler H, Kucera W, Meier W, et al. Flow properties of blood and hemoreological methods of quantification. in: Physical Characterization of Biological cells. Basic research and clinic relevance. Ed. W. Scütt, H. Klinkmann, I. Lamprecht, T. Wilson, Verlag Gesundheit GmbH Berlin, 189-214, 1991.

[10] Chmiel H. Determination of blood rheological parameters and clinical application. Advances in Cardiovascular Physics 1979;3:1-44.

[11] Czerwiński F, Kopczyńska DL, Musioł AA, Słowińska AM, Włodarczyk PM, Wysocka E, Marcinkowska- 
Gapińska A. Lepkość krwi jako czynnik reologiczny w patogenezie chorób naczyniowych. in: Biofizyka a medycyna. T.8. red. nauk.: Leszek Kubisz, Dorota Hojan-Jezierska, Teresa Matthews-Brzozowska, Anna Marcinkowska-Gapińska, Poznań Wydaw. Uniw. Med. im. Karola Marcinkowskiego w Poznaniu, 2019 S. 32-58.

[12] Jain RK. Determinants of Tumor Blood Flow: A Review. Cancer Research 1988;48: 2641-2658.

[13] Khan MM, Puniyani RR, Huilgol NG, Hussain MA, Ranade G.G. Hemorheological profiles in cancer patients. Clin. Hemorheol. Microcirc. 1995;15(1):37-44.

[14] Tietien GW, Chien S, Scholz P, Gump FE, Kinney JM. Changes in blood viscosity and plasma proteins in carcinoma. J. Surg. Oncol. 1977;9:53-59.

[15] Tempelhoff GF, Heilmann L, Hommel G, Pollow K. Impact of rheological variables in cancer. Semin. Thromb. Hemost. 2003;29(5):499-514.

[16] Kowal P, Marcinkowska-Gapińska A. Hemorheological changes dependent on the time from the onset of ischemic stroke. J. Neurol. Sci. 2007;258:132-136.

[17] Dintenfass L. Clinical Applications of blood viscosity factors and functions: Especially in the cardiovascular disorders. Biorheology 1979;16:69-84.

[18] Matsushima K, Hakim AM. Transient forebrain ischemia protects against subsequent focal cerebral ischemia without changing cerebral perfusion. Stroke 1995;26:1047-1052.

[19] Murry CE, Jennings RB, Reimer K.A. Preconditioning with ischemia, a delay of lethal cell injury in ischemic myocardium. Circulation 1986;74:1124-1136.

[20] Reinhart WH. Molecular biology and self-regulatory mechanisms of blood viscosity: A review. Biorheology 2000;38:203-212.

[21] Kwaan H.C. Role of plasma proteins in whole blood viscosity: A brief clinical review. Clin. Hemoreol. Microcirc. 2010;44(3):167-176.

[22] Bouhmadi AE, Laffargue F, Brun JF. Aggregability and disaggregability of erythrocytes in women suffering from ovarian cancer: evidence for an increased disaggregation threshold. Clin. Hemorheol. Microcirc., 2000;22:91-97.

[23] Marcinkowska-Gapińska A, Kowal P. Hemorheological studies of chosen clinical cases. J. Med. Sci. [d. Now. Lek.] 2015;84(3):197-200.

[24] Miller B, Heilmann L. Hemorheological parameters in patients with gynecologic malignancies. Gynecologic Oncology 1989;33(2):177-181.

[25] Jirtle RI. Chemical modification of tumor blood flow. Int J Hyperthermia 1988;4:355-371.

[26] Horsman MR, Chaplin DJ, Overgaard J. The use of blood flow modifiers to improve the treatment response of solid tumors. Radiotheraphy and Oncology 1991;20:47-52.

[27] Yu J, Han M, Geng J. Influence of propofol intravenous anesthesia on hemorheology, haemodynamics and immune function of colorectal carcinoma patients undergoing radical resection. Pak J Med Sci. 2019;35(3):780-785.

[28] Tempelhoff GF, Heilmann L, Pollow K, Hommel G. Monitoring of rheologic variables during postoperative high-dose brachytherapy for uterine cancer. Clin. Appl., Thromb. Hemost. 2004;10(3):239-248.

[29] Reinhart WH. The optimum hematocrit. Clin. Hemorheol. Microcirc. 2016;64:575-585.

[30] Tikhomirova I, Petrochenko E, Malysheva Y, Ryabovb M, Kislov N. Interrelation of blood coagulation and hemorheology in cancer. Clin. Hemorheol. Microcirc. 2016;64: 635-644.

[31] Baronzio G, Freitas I, Kwaan HC. Tumor Microenvironment and Hemorheological Abnormalities. Semin. Thromb. Hemost. 2003;29(5):489-498.

[32] Tempelhoff GH, Schönmann N, Heilmann L, Pollow K, Hommel G. Prognostic role of plasmaviscosity in breast cancer. Clin. Hemorheol. Microcirc. 2002;26:55-61.

[33] Tempelhoff GF, Niemann F, Schneider DM, Kirkpatrick CJ, Hommel G, Heilmann L. Blood Rheology during Chemotherapy in Patients with Ovarian Cancer. Thrombosis Research 1998;90:73-82.

[34] Caimi G, Hopps E, Carlisi M, Montana M, Gall `a E, Presti R.L, Siragusa S. Hemorheological parameters in Monoclonal Gammopathy of Undetermined Significance (MGUS). Clin. Hemorheol. Microcirc. 2018;68:51-59.

[35] Spivak JL, Gascon P, Ludwig H. Anemia Management in Oncology and Hematology. The Oncologist 
2009;14:43-56.

[36] Kader AS, Lim JT, Berthelet E, Petersen R, Ludgate D, Truong PT. Prognostic Significance of Blood Transfusions in Patients with Esophageal Cancer Treated with Combined Chemoradiotherapy. Am. J. Clin. Oncol. 2007;30(5):492-497.

[37] Muravyow AV, Cheporov SV, Kislov NV, Bulaeva SV, Maimistova AA. Comparative efficiency and hemorheological consequecnes of hemotransfusion and epoetin therapy in anemic cancer patients. Clin. Hemorheol. Microcirc. 2010;44(2):115-123.

[38] Wlodkowic D, Cooper JM. Tumors on chips: oncology meets microfluidies. Curr. Opin. Chem. Biol. 2010;14(5):556-567.

[39] Uggla B, Nilson TK. Whole blood viscosity in plasma cell dyscrasias. Clin. Biochem. 2015;48:122-124.

[40] MacKenzie MR, Lee TK. Blood viscosity in Waldenström macroglobulinemia. Blood 1977;49(4):507-510.

[41] Treon SP, Branagan AR, Hunter Z, Santos D, Tournhilac O, Anderson KC. Paradoxical increases in serum IgM and viscosity levels following rituximab in Waldenstrom's macroglobulinemia. Annals of Oncology 2004;15(10):1481-1483.

[42] Shin DW, Gu JY, Kim JS, Jung JS, Shin DY, Koh Y, Kim I, Kim HK. Increased plasma viscosity in plasma cell dyscrasia and whole blood viscosity in polycythemia vera. Clin. Hemorheol. Microcirc. 2018;70:5967.

[43] Wang N, Liu L, Jiang X, Li D, Chen X. Acute multiple cerebral infarction combined with cerebral microhemorrhage in Polycythemia vera: A case report. Exp. Ther. Med. 2019;18:2949-2955.

[44] Utkan G, Tek I, Kocer M, Muallaoglu S, Durnalı AG, Arslan UY, Celenkoglu G, Tokluoglu S, Alkis N. Blood Viscosity in Patients with diffuse large B cell non-hodgkin's lymphoma. Exp. Oncol. 2006;28(4):326327.

[45] Caimi G, Carlisi M, Montana M, Gall `a E, Presti RL, Hopps E, Siragusa S. Erythrocyte deformability and hemorheological profile in multiple myeloma. Clin. Hemorheol. Microcirc. 2018;68:25-34.

[46] Anderson IS, Kai-Yiu Y, Hillman D, Lessin LS. Multiple myeloma in a patient with sickel cell anemia: Interacting effects on blood viscosity J. Am. Med. 1975;59(4):568-574.

[47] Klemencic S, Perkins J. Diagnosis and Management of Oncologic Emergencies. West. J. Emer. Med. 2019;20(2):316-322.

[48] Djavanmard MP, Michl I, Korpan M, Fazeny B, Budinsky AC, Wiesinger E, Weinländer G, Binder M, Püspök M, Zielinski CC, Fialka V, Koppensteiner R, Marosi Ch. Impaired hemorheology in patients with postmastectomy lymphedema. Breast Cancer Res. Tr. 1996;38(3):283-288.

[49] Chen G, Zhao L, Liu Y, Liao F, Han D, Zhou H. Regulation of blood viscosity in disease prevention and treatment. Chin. Sci. Bull. 2012;57(16):1946-1952.

[50] Falanga A, Marchetti M, Vignoli A. Coagulation and cancer: biological and clinical aspects. J. Thromb. Haemost. 2013;11:223-233. 